\title{
An updated review of current concepts in the management of carotid stenosis
}

\author{
Norman R Hertzer
}

Address: Department of Vascular Surgery, Cleveland Clinic Emeritus Office, 3050 Science Park Drive (AC334), Beachwood, OH 44122, USA

Email: hertzen@ccf.org

Fl000 Medicine Reports 2010, 2:91 (doi:10.3410/M2-91)

This is an open-access article distributed under the terms of the Creative Commons Attribution-Non Commercial License (http://creativecommons.org/licenses/by-nc/3.0/legalcode), which permits unrestricted use, distribution, and reproduction in any medium, provided the original work is properly cited. You may not use this work for commercial purposes.

The electronic version of this article is the complete one and can be found at: http://f $1000 . c o m / r e p o r t s / m / 2 / 9$ |

\begin{abstract}
Several large randomized clinical trials in North America and Europe concluded over a decade ago that carotid endarterectomy plus medical management was significantly better than medical management alone for stroke prevention in either symptomatic or asymptomatic patients with severe carotid stenosis. Percutaneous carotid angioplasty now represents yet another treatment option that currently appears to have a higher risk than endarterectomy in symptomatic patients as well as in those who are 70 years of age or older. For these reasons, there is a consensus that angioplasty should be used cautiously in such patients and probably remains most appropriate either in the context of ongoing randomized trials or for patients who are at a higher-than-average risk for conventional surgical treatment.
\end{abstract}

\section{Introduction and context}

Few modern clinical problems have provoked as much controversy as extracranial carotid artery disease. Prompted by concern that carotid endarterectomy (CEA) was being performed for uncertain indications during the 1980s, four randomized clinical trials (RCTs) were sponsored by the National Institutes of Health in the United States and by the Medical Research Council in the United Kingdom in order to determine the benefit of CEA in symptomatic patients and for asymptomatic carotid stenosis. These included the North American Symptomatic Carotid Endarterectomy Trial (NASCET) $[1,2]$, the European Carotid Surgery Trial (ECST) [3-5], the Asymptomatic Carotid Atherosclerosis Study (ACAS) [6] and the Asymptomatic Carotid Surgery Trial (ACST) $[7,8]$, all of which remain the foundation for proper patient selection and should be thoroughly familiar to clinicians who recommend or perform any kind of carotid intervention.

Table 1 contains data from these four important investigations. It must be noted that the methods for estimating the percentage of carotid stenosis differed in the North American (NASCET, ACAS) and the European (ECST, ACST) trials. The former used the diameter of the uninvolved internal carotid artery distal to the index lesion as the denominator, whereas the latter employed the projected normal diameter of the internal carotid bulb. Nevertheless, the conclusions reached by these trials were reasonably consistent and can be summarized as follows.

First, the 30-day combined stroke or mortality rates for CEA were two to three times higher in symptomatic patients than in patients who had asymptomatic carotid stenosis. This may reflect the potential of symptomatic lesions to cause intraoperative cerebral emboli during carotid manipulation.

Second, the benefit of CEA was greater and became obvious within shorter periods of follow-up in patients who had previous symptoms in conjunction with severe carotid stenosis measuring at least $70 \%$ of lumen diameter. The relative risk reduction associated with CEA for $50-69 \%$ stenosis was only marginally significant $(P=0.045)$ in the NASCET, and the ECST showed no 
Table I. Selected data from influential randomized clinical trials (RCTs) comparing carotid endarterectomy versus medical management for stroke prevention

\begin{tabular}{|c|c|c|c|c|c|c|c|}
\hline \multirow[t]{2}{*}{ RCT } & \multirow{2}{*}{$\begin{array}{l}\text { Severity of } \\
\text { stenosis (\%) }\end{array}$} & \multirow{2}{*}{$\begin{array}{l}\text { 30-day surgical } \\
\text { CSM (\%) }\end{array}$} & \multirow{2}{*}{$\begin{array}{l}\text { Reported follow- } \\
\text { up period (yrs) }\end{array}$} & \multicolumn{2}{|c|}{ Long-term primary event rate } & \multirow{2}{*}{$\begin{array}{l}\text { Relative risk } \\
\text { reduction (\%) }\end{array}$} & \multirow[t]{2}{*}{$P$ value } \\
\hline & & & & $\begin{array}{l}\text { Carotid } \\
\text { endarterectomy (\%) }\end{array}$ & $\begin{array}{l}\text { Medical } \\
\text { management (\%) }\end{array}$ & & \\
\hline \multicolumn{8}{|l|}{$\begin{array}{l}\text { Symptomatic } \\
\text { patients }\end{array}$} \\
\hline NASCET [I] & $70-99$ & 5.8 & 2 & $9.0^{\mathrm{a}}$ & $26.0^{\mathrm{a}}$ & 65 & $<0.001$ \\
\hline NASCET [2] & $50-69$ & 6.7 & 5 & $15.7^{\mathrm{a}}$ & $22.2^{\mathrm{a}}$ & 29 & 0.045 \\
\hline ECST [3] & $70-99$ & 7.5 & 3 & $12.3^{\mathrm{b}}$ & $21.9^{b}$ & 45 & $<0.01$ \\
\hline ECST $[4,5]$ & $50-69$ & 7.9 & 8 & $18.4^{\mathrm{b}}$ & $15.6^{\mathrm{b}}$ & None & - \\
\hline \multicolumn{8}{|l|}{$\begin{array}{l}\text { Asymptomatic } \\
\text { patients }\end{array}$} \\
\hline ACAS [6] & $60-99$ & 2.3 & 5 & $5.1^{\mathrm{a}}$ & $11.0^{\mathrm{a}}$ & 53 & 0.004 \\
\hline ACST [7] & $60-99$ & 3.1 & 5 & $6.4^{c}$ & $11.8^{c}$ & 46 & $<0.0001$ \\
\hline ACST [8] & $60-99$ & 3.1 & 10 & $13.4^{\mathrm{b}}$ & $17.9^{\mathrm{b}}$ & 25 & 0.009 \\
\hline
\end{tabular}

risk reduction at all for CEA in this particular group of patients. Some symptomatic subgroups appeared to derive more benefit from CEA, including patients who were 75 years of age or older as well as those who had more than $90 \%$ stenosis, ulcerated plaques, or recent transient ischemic attacks within 2 weeks of randomization [9].

Third, in comparison to symptomatic patients in the NASCET and ECST, patients with asymptomatic carotid stenosis in the ACAS and the ACST had lower long-term event rates irrespective of whether they were allocated to CEA or medical management. Furthermore, while CEA provided a significant overall reduction of relative risk in the ACAS, this benefit seemed substantially less impressive in women than in men $(17 \%$ versus $66 \% ; P=0.10)$, probably because they tended to have a higher incidence of perioperative stroke or death $(3.6 \%$ versus $1.7 \% ; P=0.12$ ).

Fourth, the ACST did not substantiate the apparent lesser benefit of CEA that was found in asymptomatic women by the ACAS, but this might be related to the fact that the ACST excluded the risk for perioperative stroke or death (3.6\% in women, $2.5 \%$ in men) from its subset analyses. The ACST also reported that unoperated patients with $60-79 \%$ stenosis were as likely as those with $80-99 \%$ stenosis to have future strokes. The ACAS had limited arteriographic data with which to further stratify its criterion of $60-99 \%$ stenosis, but other non-randomized case series have strongly suggested that asymptomatic $60-79 \%$ stenosis has a very low risk for stroke and can be kept under surveillance by duplex scanning [10].

Fifth, the 'number needed to treat' (NNT) is defined as the number of patients who would have to undergo CEA in order to prevent one long-term adverse event. In the NASCET, this ranged from an NNT of 6 for patients who had $70-99 \%$ stenosis [1] to an NNT of 15 for patients with $50-69 \%$ stenosis $[1,2]$. The corresponding NNT was 19 for all patients in the ACAS and undoubtedly was even higher in women [6], while the NNT in the ACST was 20 [8]. In summary, CEA must be performed in substantially more asymptomatic patients before one can gain the advantage of stroke prevention.

\section{Recent advances}

Percutaneous carotid angioplasty (PCA) was described in isolated case reports during the late 1970s and has since been the topic of more than 20 large case series, over a dozen industry-sponsored registries, and several independent trials [11]. Many of these studies became obsolete almost immediately because of additional refinements in endovascular technology, such as carotid stents and over-the-wire cerebral embolic protection devices [12]. Table 2 summarizes the results from six RCTs that were published in peer-reviewed journals [13-22] and frequently have been cited on the basis of their timeliness or their controversial aspects, depending on the perspective from which they are viewed [23].

\section{CAVATAS}

Conducted from 1992 to 1997, the Carotid and Vertebral Artery Transluminal Angioplasty Study (CAVATAS) was the earliest trial of PCA versus CEA to be independently funded and to capture international attention. Each of the participating centers had to designate one or more radiologists with prior training in angioplasty techniques, but there was no requirement for previous experience with the carotid artery. The initial CAVATAS disclosures revealed no outcome differences between PCA and CEA 
Table 2. Selected data from major multicentered randomized clinical trials (RCTs) comparing carotid endarterectomy to percutaneous carotid angioplasty

\begin{tabular}{|c|c|c|c|c|c|c|c|c|c|c|}
\hline \multirow[t]{2}{*}{ RCT } & \multicolumn{2}{|c|}{ Clinical features } & \multicolumn{2}{|c|}{$\begin{array}{l}\text { Angioplasty } \\
\text { adjuncts }\end{array}$} & \multicolumn{3}{|c|}{$\begin{array}{l}\text { 30-day primary outcome } \\
\text { event rates }\end{array}$} & \multicolumn{3}{|c|}{ Long-term primary outcome event rates } \\
\hline & $\begin{array}{l}\text { Symptoms } \\
(\%)\end{array}$ & $\begin{array}{l}\text { Stenosis } \\
(\%)\end{array}$ & $\begin{array}{l}\text { Stent } \\
\text { (\%) }\end{array}$ & $\begin{array}{l}\text { CEP } \\
(\%)\end{array}$ & $\begin{array}{l}\text { CEA } \\
(\%)\end{array}$ & $\begin{array}{l}\text { PCA } \\
(\%)\end{array}$ & $P$ value & $\begin{array}{l}\text { CEA } \\
(\%)\end{array}$ & $\begin{array}{l}\text { PCA } \\
(\%)\end{array}$ & $P$ value \\
\hline $\begin{array}{l}\text { CAVATAS } \\
{[13,14]}\end{array}$ & 97 & Mean, $85 \pm 10$ & 26 & None & $9.9^{\mathrm{a}}$ & $10^{\mathrm{a}}$ & NS & $\begin{array}{l}14.2^{\mathrm{b}}(3 \text { years }) \\
50.4 \pm 4.1^{\mathrm{a}} \\
(8 \text { years })\end{array}$ & $\begin{array}{l}14.3^{\mathrm{b}}(3 \text { years }) \\
\left.45.2 \pm 4.0^{\mathrm{a}} \text { ( } 8 \text { years }\right)\end{array}$ & 0.9 \\
\hline $\begin{array}{l}\text { SAPPHIRE } \\
{[15,16]}\end{array}$ & 29 & $\begin{array}{l}\geq 50 \text { (symptomatic); } \\
\geq 80 \text { (asymptomatic) }\end{array}$ & 100 & 100 & $9.8^{d}$ & $4.8^{\mathrm{d}}$ & 0.09 & $\begin{array}{l}\left.20.1^{\mathrm{e}} \text { (I year }\right) \\
30.3^{\mathrm{e}}(3 \text { years })\end{array}$ & $\begin{array}{l}12.2^{\mathrm{e}}(\mathrm{I} \text { year }) \\
26.2^{\mathrm{e}}(3 \text { years })\end{array}$ & $\begin{array}{l}0.05 \\
0.71\end{array}$ \\
\hline SPACE $[17,18]$ & 100 & $\begin{array}{l}\geq 50 \% \text { (NASCET) } \\
\geq 70 \% \text { (ECST) }\end{array}$ & 100 & 27 & $6.3^{f}$ & $6.8^{f}$ & 0.09 & $8.8^{\mathrm{g}}$ & $9.5^{g}$ & 0.62 \\
\hline EVA-3S $[19,20]$ & 100 & $\geq 60 \%$ & 100 & 92 & $3.9^{\mathrm{h}}$ & $9.6^{h}$ & 0.01 & $\begin{array}{l}4.2^{\mathrm{i}} \text { ( } 6 \text { months) } \\
6.2^{\mathrm{i}} \text { (4 years) }\end{array}$ & $\begin{array}{l}10.2^{\mathrm{i}} \text { (6 months) } \\
\text { II.I' (4 years) }\end{array}$ & $\begin{array}{l}0.008 \\
0.03\end{array}$ \\
\hline $\begin{array}{l}\text { ICSS [2I] } \\
\text { CREST [22] }\end{array}$ & $\begin{array}{l}100 \\
53\end{array}$ & $\begin{array}{l}\geq 50 \% \\
\geq 50 \text { (symptomatic) } \\
\geq 60 \text { (asymptomatic) }\end{array}$ & $\begin{array}{l}92 \\
100\end{array}$ & $\begin{array}{l}72 \\
94\end{array}$ & $\begin{array}{l}4.0^{\mathrm{d}} \\
4.5^{\mathrm{d}}\end{array}$ & $\begin{array}{l}7.4^{\mathrm{d}} \\
5.2^{\mathrm{d}}\end{array}$ & $\begin{array}{l}0.003 \\
0.38\end{array}$ & $\begin{array}{l}5.2^{\mathrm{j}} \\
6.8^{\mathrm{k}}\end{array}$ & $\begin{array}{l}8.5^{\mathrm{j}} \\
7.2^{\mathrm{k}}\end{array}$ & $\begin{array}{l}0.006 \\
0.51\end{array}$ \\
\hline
\end{tabular}

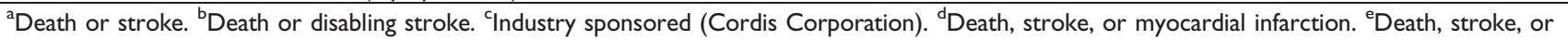
myocardial infarction within 30 days or subsequent ipsilateral stroke. ${ }^{\mathrm{f} D e a t h}$ or ipsilateral ischemic stroke. ${ }^{g}$ Death or stroke within 30 days or ipsilateral ischemic stroke within 2 years. ${ }^{h}$ Any death or stroke. 'Any death or stroke within 30 days or subsequent ipsilateral stroke. 'Death, stroke, or myocardial infarction within 120 days of randomization. ${ }^{k}$ Death, stroke, or myocardial infarction within 30 days or death or ipsilateral stroke within 4 years. CAVATAS, Carotid and Vertebral Artery Transluminal Angioplasty Study; CEA, carotid endarterectomy; CEP, cerebral embolic protection; CREST, Carotid Revascularization Endarterectomy versus Stenting Trial; ECST, European Carotid Surgery Trial criteria; EVA-3S, Endarterectomy Versus Angioplasty in Patients with Symptomatic Severe Carotid Stenosis trial; ICSS, International Carotid Stenting Study; NASCET, North American Symptomatic Carotid Endarterectomy Trial criteria; PCA, percutaneous carotid angioplasty; SAPPHIRE, Stenting and Angioplasty with Protection in Patients at High Risk for Endarterectomy trial; SPACE: Stent-Supported Percutaneous Angioplasty of the Carotid Artery versus Endarterectomy trial.

in symptomatic patients [13], but their credibility was eroded by a 30-day stroke or mortality rate for CEA $(9.9 \%)$ that was much worse than generally had been reported. Moreover, carotid stents were used in only $26 \%$ of the patients who received PCA, a factor that could have contributed to a high incidence of recurrent $\geq 70 \%$ stenosis ( $18 \%$ versus $5.2 \%$ for CEA; $P=0.0001$ ) at just 1 year of follow-up [24]. Cerebral embolic protection devices were unavailable at that time, so this adjunct was not used in the CAVATAS. For these reasons, the CAVATAS has become relatively obsolete despite the fact that it remains the only RCT of its kind to report results as long as 10 years after PCA [14].

\section{SAPPHIRE}

The Stenting and Angioplasty with Protection in Patients at High Risk for Endarterectomy (SAPPHIRE) trial was funded by industry and for this reason may not have quite the cachet of an independent RCT. It enrolled asymptomatic patients with $\geq 80 \%$ stenosis in addition to symptomatic patients with $\geq 50 \%$ stenosis, and it employed a unique primary end point of stroke, death, and/or myocardial infarction (MI). This represented a departure from the traditional composite end point of stroke and/or death, especially since it included asymptomatic elevations in cardiac isoenzyme and troponin levels that had not been measured in most previous studies of CEA. The SAPPHIRE trial did have a number of practical features, however. First, it only accepted patients who were less than ideal surgical candidates because of such things as serious cardiac (e.g., recent MI or unstable angina, congestive heart failure, or $<30 \%$ ejection fraction) or pulmonary disease, advanced age (80 years or older), contralateral internal carotid occlusion, or treacherous local anatomy (caused by high carotid lesions near the skull base, a history of cervical irradiation, or recurrent stenosis after prior CEA). Second, interventionalists were strictly vetted and had a median past experience of 64 PCAs. Third, every PCA procedure was done using a cerebral embolic protection device and a carotid stent, both of which were manufactured by the sponsor (Cordis Corporation).

Much of the difference in 30-day end points could be attributed to a higher incidence of 'chemical' MIs after CEA, but the ultimate conclusion of the trial was that PCA provided an equivalent alternative in patients who were perceived to be at high risk for CEA. The SAPPHIRE trial has been criticized on the grounds that the majority $(70 \%)$ of its patients were asymptomatic, that too many were entered into a non-randomized PCA registry because they were considered unsuitable for CEA, and that the unconventional primary end points were potentially misleading [25]. However, asymptomatic carotid disease is the most common indication for CEA or PCA in the United States [26] - and not just for the 
convincing severity of stenosis (80-99\%) that this trial required. In addition, participating surgeons may have been understandably reluctant to randomly assign certain patients who had multiple high-risk factors for CEA. Finally, although the inclusion of clinically unsuspected MIs was a novel approach to early outcome assessment, it is difficult to argue logically that these events should have been allowed to go undetected. Nevertheless, if the 30-day analysis had included only the previously conventional endpoints of stroke or death (5.5\% for PCA versus $8.4 \%$ for CEA), the difference between the treatment groups would not have been statistically significant at either 1 year [15] or 3 years [16] of follow-up.

\section{SPACE}

The Stent-Supported Percutaneous Angioplasty of the Carotid Artery versus Endarterectomy (SPACE) trial is a non-inferiority study that was designed to demonstrate equivalence between PCA/stenting and CEA. In order to participate, interventionalists had to show proof of at least 25 successful consecutive PCA procedures. The virtues of the SPACE trial are its large size (1200 symptomatic patients), which exceeded any previous RCT, and the fact that it was supported predominantly by independent resources. Its perceived liabilities are that cerebral embolic protection was used during only $27 \%$ of the PCA procedures and that recruitment was prematurely stopped for lack of funding after it was discovered that more than 2500 patients would be necessary to confirm its interim results with adequate statistical power. At that time, the 30-day risk for death or ipsilateral stroke appeared comparable for PCA and CEA ( $6.8 \%$ and $6.3 \%$, respectively), but the $P$ value for non-inferiority was only 0.9. No long-term event rates were available in the original report of the SPACE trial [17], but they now have been reported at 2 years of follow-up by Eckstein et al. [18].

\section{EVA-3S}

The Endarterectomy Versus Angioplasty in Patients with Symptomatic Severe Carotid Stenosis (EVA-3S) trial could conceivably serve as a proxy for the evolution of PCA in other large population bases. Sponsored by the French Ministry of Health in 20 academic and 10 nonacademic medical centers, this trial permitted the use of a variety of approved catheter devices. Carotid stenting was mandatory, but cerebral embolic protection (ultimately used in $92 \%$ of patients) was not routinely recommended until the 30-day stroke rate was discovered to be 3.9 (95\% confidence interval [CI] 0.9-16.7) times higher without embolic protection $(27 \%, 4$ out of 15 patients) than with protection (8.6\%, 5 out of 58 patients) in the initial 73 patients treated by PCA [27]. Perhaps the most controversial element of this trial is that interventionalists who had no previous experience with PCA still were permitted to perform it in randomly assigned patients under the supervision of tutors until they acquired the requisite number of 12 PCAs (or only 5 PCAs plus another 30 stenting procedures in aortic arch vessels) for full accreditation. (Interventionalists also could begin using a new catheter device within the trial as soon as they had gained some familiarity with it in just two other cases.) Despite this controversy, however, there was no significant difference between experienced interventionalists and those who were tutored either during or after their training with respect to 30-day combined stroke and mortality rates $(10 \%$ versus $7.1 \%$ versus $12 \%$; $P=0.54)$.

Trial enrollment was stopped on the basis of safety and futility once the 30-day stroke or mortality rate in the first 527 treated patients was found to be so much higher for PCA than for CEA (9.6\% versus $3.9 \%$; relative risk 2.5; $95 \%$ CI $1.2-5.1 ; P=0.01)$ that more than 4000 patients would have been necessary to demonstrate its noninferiority to CEA. Largely on the basis of its lower operative risk, the results of CEA have remained superior to those of PCA from 6 months [19] to 4 years [20] of follow-up. The EVA-3S trial has been criticized for the inexperience among its interventionalists and the lack of a standardized technique for PCA, but the flaws that some might find in this trial - the blend of community hospitals as well as referral centers, the mid-course changes to new or improved equipment, and the low procedural volumes or on-the-job training by more experienced colleagues - probably are ubiquitous and may make its results even more relevant to 'real world' practice [28]. The French trial was restricted to symptomatic patients, but another national dataset also showed that PCA/stenting was associated with higher risks for stroke or death than CEA in either symptomatic or asymptomatic patients in the United States during 2003 and 2004 [26].

\section{ICSS}

An interim analysis of the International Carotid Stenting Study (ICSS), a large trial comprising 1713 symptomatic patients, has reported results at a maximum of 120 days following CEA or PCA (nearly all of the PCAs used stents and cerebral protection devices) [21]. Surgeons had to have performed at least 50 carotid operations, and interventionalists who had not done a minimum of 10 carotid stenting procedures were proctored until they had completed a total of 20 acceptable cases within the trial. Among patients who actually received the treatment to which they had been assigned, the 30-day risk for 
stroke, death, or MI was significantly higher after PCA than after CEA (7.4\% versus $4.0 \%$; relative risk $1.8 ; 95 \%$ CI $1.2-2.8 ; P=0.003)$. Only four MIs occurred in the CEA group, none of which was fatal. On the basis of an intention-to-treat analysis, the 120-day risk for stroke, death, or MI still was higher in the PCA cohort $(8.5 \%$ versus $5.2 \% ; P=0.006$ ). Furthermore, in a subset of 231 patients who underwent diffusion-weighted magnetic resonance imaging both before and after carotid intervention [29], new ischemic brain lesions were documented far more frequently in the PCA group than in the CEA group (50\% versus 17\%; adjusted odds ratio 5.2; 95\% CI 2.8-9.8; $P<0.0001)$. Follow-up scans done 1 month later showed that these changes persisted in $33 \%$ of the patients who had PCA compared to only $8 \%$ of those who had CEA.

Neither the ICSS nor the SPACE or EVA-3S trials had sufficient statistical power to determine whether PCA might be an appropriate alternative to CEA in certain subgroups of symptomatic patients, but a collaborative preplanned meta-analysis of individual patient data from these three RCTs has now been conducted to address this issue [30]. Of the 16 variables that were assessed (such as age, gender, prior symptoms, the severity of ipsilateral and contralateral carotid stenosis, and hospital volume of PCA) only age proved to be a significant factor in a total of 3324 patients who had their allocated procedure. Among those who were younger than the median age of 70 years, the 30-day incidence of stroke or death was comparable for PCA and CEA ( $5.1 \%$ and $4.5 \%$, respectively). In patients who were 70 years of age or older, however, the risk of stroke or death for PCA was over twice that for CEA $(10 \%$ versus 4.4\%; risk ratio $2.4 ; 95 \%$ CI 1.6-3.5; $P=0.0078)$. Others also have found that PCA has a higher serious complication rate in older patients, probably because of the potential for catheter-directed devices to provoke cerebral emboli in the presence of the arterial tortuosity and calcification that often occur in the elderly [31-33].

\section{CREST}

The Carotid Revascularization Endarterectomy versus Stenting Trial (CREST) is the largest RCT comparing PCA to CEA yet to be reported, enrolling 1321 symptomatic and 1181 asymptomatic patients at 117 centers from 2000 to 2008 [22]. All PCA procedures were done with a stent, and cerebral embolic protection was employed in 94\% of patients. The CREST trialists used a composite primary end point defined as any periprocedural stroke, death or MI, or an ipsilateral stroke within 4 years of randomization, but they also provide data regarding stroke and death alone. According to an intention-totreat analysis at a median follow-up interval of 2.5 years, the estimated 4-year primary end point rate was equivalent for carotid artery stenting and CEA (7.2\% versus $6.8 \%$ ). This effect was not influenced by the symptomatic status $(P=0.84)$ or patient gender $(P=$ 0.34 ), but there was a crossover point leading to significantly higher risks for PCA in patients aged 70 or older $(P=0.02)$, as was the case in the collaborative meta-analysis of the ICSS, SPACE, and EVA-3S trials [30]. Whereas the 30-day incidence of MI was higher with CEA (2.3\% versus $1.1 \% ; P=0.03$ ) in the CREST, early strokes occurred more frequently with PCA ( $4.1 \%$ versus $2.3 \%$; $P=0.01)$. Finally, a prespecified secondary analysis indicated that PCA had a higher 4-year stroke or death rate than CEA (6.4\% versus 4.7\%; risk ratio 1.5 ; $95 \%$ CI $1.1-2.1 ; P=0.03)$. By comparison, PCA in the CREST was associated with a lower periprocedural stroke or death rate than any of the other RCTs in Table 2 except the SAPPHIRE trial. In this regard, it must be noted that both of these studies included a substantial number of asymptomatic patients.

\section{Implications for clinical practice}

Citing much of the material covered in this review as well as additional sources in the literature, the Society for Vascular Surgery [34] and the European Society for Vascular Surgery [35] have published practice guidelines for the management of atherosclerotic carotid artery disease. These documents reconfirmed the continued importance of the NASCET, ECST, ACAS, and ACST in the selection of patients for either surgical or catheterbased intervention, emphasizing that patients who have symptomatic $<50 \%$ stenosis or asymptomatic $<60 \%$ stenosis are well suited to optimal medical management alone. Each of the societal guidelines also suggests that CEA plus best medical therapy should remain the primary option for patients with more severe stenosis unless the ICSS and the CREST were to prove otherwise. In fact, the recently published conclusions from the ICSS and the CREST are decidedly mixed. Although both agree that PCA is associated with a higher risk for stroke or death in patients 70 years of age or older, the CREST has not confirmed the significant risk of PCA in symptomatic patients that was found in the ICSS. On the basis of these uncertainties, PCA generally seems to be most appropriate in the setting of ongoing RCTs until it has been shown conclusively to be at least as safe and durable as CEA in certain patient subsets. In the meantime, exceptions favoring PCA can be justified for patients whose medical comorbidities or cervical anatomy make them questionable candidates for CEA.

\section{Abbreviations}

ACAS, Asymptomatic Carotid Atherosclerosis Study; ACST, Asymptomatic Carotid Surgery Trial; CAVATAS, 
Carotid and Vertebral Artery Transluminal Angioplasty Study; CEA, carotid endarterectomy; CREST, Carotid Revascularization Endarterectomy versus Stenting Trial; CI, confidence interval; ECST, European Carotid Surgery Trial; EVA-3S, Endarterectomy Versus Angioplasty in Patients with Symptomatic Severe Carotid Stenosis; ICSS, International Carotid Stenting Study; MI, myocardial infarction; NASCET, North American Symptomatic Carotid Endarterectomy Trial; NNT, number needed to treat; PCA, percutaneous carotid angioplasty; RCT, randomized clinical trial; SAPPHIRE, Stenting and Angioplasty with Protection in Patients at High Risk for Endarterectomy; SPACE, Stent-Supported Percutaneous Angioplasty of the Carotid Artery versus Endarterectomy.

\section{Competing interests}

The author was a participating surgeon in the SAPPHIRE trial but had no role in the design of the trial, the management or interpretation of its data, or the preparation of its published reports.

\section{References}

I. North American Symptomatic Carotid Endarterectomy Trial Collaborators: Beneficial effect of carotid endarterectomy in symptomatic patients with high-grade carotid stenosis. $\mathrm{N}$ Engl J Med 199I, 325:445-53.

2. Barnett HJM, Taylor DW, Eliasziw M, Fox AJ, Ferguson GG, Haynes RB, Rankin RN, Clagett GP, Hachinski VC, Sackett DL, Thorpe KE, Meldrum HE, Spence JD; North American Symptomatic Carotid Endarterectomy Trial Collaborators: Benefit of carotid endarterectomy in patients with symptomatic moderate or severe stenosis. N Engl J Med 1998, 339:1415-25.

3. European Carotid Surgery Trialists' Collaborative Group: MRC European Carotid Surgery Trial: interim results for symptomatic patients with severe $(70-99 \%)$ or with mild $(0-29 \%)$ carotid stenosis. Lancet 1991, 337:1235-43.

4. European Carotid Surgery Trialists' Collaborative Group: Endarterectomy for moderate symptomatic carotid stenosis: interim results from the MRC European Carotid Surgery Trial. Lancet 1996, 347:159|-3.

5. European Carotid Surgery Trialists' Collaborative Group: Randomised trial of endarterectomy for recently symptomatic carotid stenosis: final results of the MRC European Carotid Surgery Trial (ECST). Lancet 1998, 351: 1379-187.

6. Executive Committee for the Asymptomatic Carotid Atherosclerosis Study: Endarterectomy for asymptomatic carotid artery stenosis. JAMA 1995, 273:142I-8.

7. Halliday A, Mansfield A, Marro J, Peto C, Peto R, Potter J, Thomas D; MRC Asymptomatic Carotid Surgery Trial (ACST) Collaborative Group: Prevention of disabling and fatal strokes by successful carotid endarterectomy in patients without recent neurological symptoms: randomised controlled trial. Lancet 2004, 363:| $149 \mid-502$.

8. Halliday A, Harrison M, Hayter E, Kong X, Mansfield A, Marro J, Pan H, Peto R, Potter J, Rahimi K, Rau A, Robertson S, Streifler J, Thomas D; Asymptomatic Carotid Surgery Trial (ACST) Collaborative Group: 10-year stroke prevention after successful carotid endarterectomy for asymptomatic stenosis (ACST-I): a multicentre randomised trial. Lancet 2010, 376:1074-84.

FI000 Factor 8

Evaluated by Norman Hertzer 20 Oct 2010

9. Rothwell PM, Eliasziw M, Gutnikov SA, Warlow CP, Barnett HJ; Carotid Endarterectomy Trialists Collaboration: Endarterectomy for symptomatic carotid stenosis in relation to clinical subgroups and timing of surgery. Lancet 2004, 363:9/5-24.

10. Olin JW, Fonseca C, Childs MB, Piedmonte MR, Hertzer, NR, Young JR: The natural history of asymptomatic moderate internal carotid artery stenosis by duplex ultrasound. Vasc Med 1998, 3:101-8.

II. Goodney PP, Powell RJ: Carotid artery stenting: what have we learned from the clinical trials and registries and where do we go from here? Ann Vasc Surg 2008, 22: I 48-58.

12. Kastrup A, Gröschel K, Krapf H, Brehm BR, Dichgans J, Schulz JB: Early outcome of carotid angioplasty and stenting with and without cerebral protection devices: a systematic review of the literature. Stroke 2003, 34:813-9.

13. CAVATAS Investigators: Endovascular versus surgical treatment in patients with carotid stenosis in the Carotid and Vertebral Artery Transluminal Angioplasty Study (CAVATAS): a randomised trial. Lancet 200I, 357:1729-37.

14. Ederle J, Bonati LH, Dobson J, Featherstone RL, Gaines PA, Beard JD, Venables GS, Markus HS, Clifton A, Sandercock P, Brown MM; CAVATAS investigators: Endovascular treatment with angioplasty or stenting versus endarterectomy in patients with carotid artery stenosis in the Carotid And Vertebral Artery Transluminal Angioplasty Study (CAVATAS): long-term follow-up of a randomised trial. Lancet Neurol 2009, 8:898-907.

FI000 Factor II

Evaluated by Norman Hertzer 03 Dec 2009, Thomas Milhorat 05 Jan 2010

15. Yadav JS, Wholey MH, Kuntz RE, Fayad P, Katzen BT, Mishkel GJ, Bajwa TK, Whitlow P, Strickman NE, Jaff MR, Popma J], Snead DB, Cutlip DE, Firth BG, Ouriel K; Stenting and Angioplasty with Protection in Patients at High Risk for Endarterectomy Investigators: Protected carotid-artery stenting versus endarterectomy in high-risk patients. N Engl J Med 2004, 35 I: | 493-50I.

16. Gurm HS, Yadav JS, Fayad P, Katzen BT, Mishkel GJ, Bajwa TK, Ansel G, Strickman NE, Wang H, Cohen SA, Massaro JM, Cutlip DE; SAPPHIRE investigators: Long-term results of carotid stenting versus endarterectomy in high-risk patients. N Engl J Med 2008, 358: $1572-9$.

FI000 Factor 6

Evaluated by Norman Hertzer 18 Apr 2008

17. SPACE Collaborative Group, Ringleb PA, Allenberg J, Brückmann H, Eckstein HH, Fraedrich G, Hartmann M, Hennerici M, Jansen O, Klein G, Kunze A, Marx P, Niederkorn K, Schmiedt W, Solymosi L, Stingele R, Zeumer $\mathrm{H}, \mathrm{Hacke} W: \mathbf{3 0}$ day results from the SPACE trial of stentprotected angioplasty versus carotid endarterectomy in symptomatic patients: a randomised non-inferiority trial. Lancet 2006, 368: 1239-47.

FI000 Factor 8

Evaluated by Hans-Christoph Diener 06 Dec 2006

18. Eckstein HH, Ringleb P, Allenberg JR, Berger J, Fraedrich G, Hacke W, Hennerici M, Stingele R, Fiehler J, Zeumer H, Jansen O: Results of the Stent-Protected Angioplasty versus Carotid Endarterectomy (SPACE) study to treat symptomatic stenoses at 2 years: a multinational, prospective, randomised trial. Lancet Neurol 2008, 7:893-902.

19. Mas JL, Chatellier G, Beyssen B, Branchereau A, Moulin T, Becquemin JP, Larrue V, Lièvre M, Leys D, Bonneville JF, Watelet J, Pruvo JP, Albucher JF, Viguier A, Piquet P, Garnier P, Viader F, Touzé E, Giroud M, Hosseini H, Pillet JC, Favrole P, Neau JP, Ducrocq X; EVA-3S investigators: Endarterectomy versus stenting in patients with symptomatic severe carotid stenosis. $N$ Engl J Med 2006, 355: 1660-7|.

FI000 Factor 8

Evaluated by Norman Hertzer 27 Jul 2007

20. Mas JL, Trinquart L, Leys D, Albucher JF, Rousseau H, Viguier A, Bossavy JP, Denis B, Piquet P, Garnier P, Viader F, Touzé E, Julia P, Giroud M, Krause D, Hosseini H, Becquemin JP, Hinzelin G, 
Houdart E, Hénon H, Neau JP, Bracard S, Onnient Y, Padovani R, Chatellier G; EVA-3S investigators: Endarterectomy Versus Angioplasty in Patients with Symptomatic Severe Carotid Stenosis (EVA-3S) trial: results up to 4 years from a randomised, multicentre trial. Lancet Neurol 2008, 7:885-92.

21. International Carotid Stenting Study investigators, Ederle J, Dobson J, Featherstone RL, Bonati LH, van der Worp HB, de Borst G], Lo TH, Gaines P, Dorman PJ, Macdonald S, Lyrer PA, Hendriks JM, McCollum C, Nederkoorn PJ, Brown MM: Carotid artery stenting compared with endarterectomy in patients with symptomatic carotid stenosis (International Carotid Stenting Study): an interim analysis of a randomised controlled trial. Lancet 2010, 375:985-97.

FI000 Factor 12

Evaluated by Shailendra Joshi II Mar 2010, Seemant Chaturvedi 29 Apr 2010, Jon Matsumura 10 May 2010

22. Brott TG, Hobson RW 2nd, Howard G, Roubin GS, Clark WM, Brooks W, Mackey A, Hill MD, Leimgruber PP, Sheffet AJ, Howard VJ, Moore WS, Voeks JS, Hopkins LN, Cutlip DE, Cohen DJ, Popma JJ, Ferguson RD, Cohen SN, Blackshear JL, Silver FL, Mohr JP, Lal BK, Meschia JF; CREST Investigators: Stenting versus endarterectomy for treatment of carotid-artery stenosis. N Engl J Med 2010, 363: $11-23$

FI000 Factor 27

Evaluated by Norman Hertzer 21 Jun 2010, Eric Heyer 30 Jun 2010, Sripal Bangalore 05 Jul 2010, Bo Norrving 13 Jul 2010, Philippa Newfield 02 Aug 2010, Paul Pagel 09 Sep 2010, Mark Alberts II Oct 2010, Thomas Milhorat 28 Sep 2010, Jon Matsumura 02 Nov 2010

23. Branchereau A, Macdonald S, Wholey MH, Green R, Gray W: Perspectives on recent CAS trial data. Endovascular Today 2007, 2:22-49. [http://bmctoday.net/evtoday/2007/02/]

24. McCabe DJH, Pereira AC, Clifton A, Bland JM, Brown MM; CAVATAS Investigators: Restenosis after carotid angioplasty, stenting, or endarterectomy in the Carotid and Vertebral Artery Transluminal Angioplasty Study (CAVATAS). Stroke 2005, 36:28I-6.

25. Thomas DJ: Protected carotid artery stenting versus endarterectomy in high-risk patients. Reflections from SAPPHIRE. Stroke 2005, 36:912-3.

26. McPhee JT, Hill JS, Ciocca RG, Messina LM, Eslami MH: Carotid endarterectomy was performed with lower stroke and death rates than carotid artery stenting in the United States in 2003 and 2004. J Vasc Surg 2007, 46: $1112-8$.

FI000 Factor 6

Evaluated by Harri Jenkins 02 Jun 2008

27. Mas JL, Chatellier G, Beyssen B; EVA-3S Investigators: Carotid angioplasty and stenting with and without cerebral protection: clinical alert from the Endarterectomy Versus Angioplasty in Patients With Symptomatic Severe Carotid Stenosis (EVA-3S) trial. Stroke 2004, 35:el 8-20.

28. Naylor AR: Where next after SPACE and EVA-3S: 'The good, the bad and the ugly!'. Eur J Vasc Endovasc Surg 2007, 33:44-7.

29. Bonati LH, Jongen LM, Haller S, Flach HZ, Dobson J, Nederkoorn PJ, Macdonald S, Gaines PA, Waaijer A, Stierli P, Jäger HR, Lyrer PA, Kappelle LJ, Wetzel SG, van der Lugt A, Mall WP, Brown MM, van der Worp HB, Engelter ST; ICSS-MRI study group: New ischaemic brain lesions on MRI after stenting or endarterectomy for symptomatic carotid stenosis: a substudy of the International Carotid Stenting Study (ICSS). Lancet Neurol 2010, 9:353-62.

FI000 Factor 9

Evaluated by Norman Hertzer 19 Apr 2010, Conrado Estol 13 May 2010

30. Carotid Stenting Trialists' Collaboration, Bonati LH, Dobson J, Algra A, Branchereau A, Chatellier G, Fraedrich G, Mali WP, Zeumer H, Brown MM, Mas JL, Ringleb PA: Short-term outcome after stenting versus endarterectomy for symptomatic carotid stenosis: a preplanned meta-analysis of individual patient data. Lancet 2010, 376:1062-73.

FI000 Factor 12

Evaluated by Seemant Chaturvedi 04 Oct 2010, Norman Hertzer 07 Oct 2010, Jerome Fleg 14 Oct 2010

3I. Hobson RW 2nd, Howard VJ, Roubin GS, Brott TG, Ferguson RD, Popma JJ, Graham DL, Howard G; CREST investigators: Carotid artery stenting is associated with increased complications in octogenarians: 30-day stroke and death rates in the CREST lead-in phase. J Vasc Surg 2004, 40: I I06-II.

32. Stanziale SF, Marone LK, Boules TN, Brimmeier JA, Hill K, Makaroun MS, Wholey MH: Carotid artery stenting in octogenarians is associated with increased adverse outcomes. J Vasc Surg 2006, 43:297-304.

33. Lam RC, Lin SC, DeRubertis B, Hynecek R, Kent KC, Faries PL: The impact of increasing age on anatomic factors affecting carotid angioplasty and stenting. J Vasc Surg 2007, 45:875-80.

34. Hobson RW 2nd, Mackey WC, Ascher E, Murad MH, Calligaro KD, Comerota AJ, Montori VM, Eskandari MK, Massop DW, Bush RL, Lal BK, Perler BA; Society for Vascular Surgery: Management of atherosclerotic carotid artery disease: clinical practice guidelines of the Society for Vascular Surgery. J Vasc Surg 2008, 48:480-6.

35. Liapis CD, Bell PRF, Mikhailidis D, Sivenius J, Nicolaides A, Fernandes e Fernandes J, Biasi G, Norgren L; ESVS Guidelines Collaborators: ESVS Guidelines. Invasive treatment for carotid stenosis: indications, techniques. Eur J Vasc Endovasc Surg 2009, 37 (Suppl 4): I-19. 